\title{
"All the time, somebody listens in": mirror images of social paranoia in twentieth-century American and Soviet literature
}

\author{
Miranda Corcoran
}

School of English, UCC

\section{Introduction}

Emphasising the manner in which literary texts often serve to express the collective hopes and fears of their respective cultures or communities, my research explores the representation of social paranoia in a selection of Cold War American and Soviet Russian novels. Although the antagonism between these two opposing superpowers, and their struggle for ideological supremacy, shaped the course of twentieth- century international relations, my research proposes that an examination of the literary and cultural output of these two apparently irreconcilable socio-political systems reveals a parallel preoccupation with a number of typically paranoid concerns. These shared anxieties include the unsettling reality of state surveillance and similar methods of social control, the ever-present threat of enemy infiltration, and the politicisation of science which resulted in the terror of the Nuclear Age.

Indeed, much of the fiction produced in Russia from the Stalinist era onwards and in the U.S. during the Cold War period highlights the manner in which these two seemingly incompatible cultures were consumed by similar fears and gripped by an equally pervasive paranoia. The central thesis of my research maintains that these parallel conditions of anxiety and mistrust led to surprisingly similar literary responses, which transcended the ideological divide between capitalism and Communism and, as such, highlighted the uniformity of fear which lay beneath the façade of largely constructed difference.

For the purposes of this article, I will examine two novels whose analysis forms an integral part of my PhD thesis, Mikhail Bulgakov's The Master and Margarita (completed 1940) and Thomas Pynchon's The Crying of Lot 49 (1966). In particular, this article will discuss how these texts engage with themes of observation and surveillance, and, in doing so, will attempt to highlight the manner in which these novels depict two seemingly divergent cultures as mirror images of paranoia and suspicion. Although this article will focus only on the manner in which key scenes from both texts demonstrate aesthetic parallels in their respective representations of paranoia, my research ultimately maintains that texts such 
as The Master and Margarita and The Crying of Lot 49 fit into a much broader discourse of fear and anxiety. Approaching these works from a historical as well as a psychoanalytic perspective, my research explores how these two novels, along with numerous other texts, both Soviet and American, succeeded in countering rigid notions of Cold War Otherness by revealing two nations possessed by a similar sense of vulnerability and insecurity.

\section{The Narrative of Otherness}

Central to my research is an in-depth analysis of the cultural and ideological context from which these texts emerged, as my thesis maintains that the continued momentum of the Cold War conflict depended largely upon the manner in which both the Soviet Union and the United States constructed their respective adversaries as utterly alien and inherently threatening. Indeed, the Cold War conflict was framed in the political rhetoric of both sides as a conflict between diametrically-opposed adversaries, an unending battle between capitalism and Communism, theism and atheism, freedom and oppression. As such, the continuance of the Cold War as an ideological conflict hinged upon a psycho-social process known as "Othering". A pervasive psychological and cultural practice, "Othering" is the process by which both individuals and groups construct and solidify their identities by investing the self with all that is moral/right and the Other or enemy with all that is abhorrent and repulsive. In the context of the Cold War, this "Othering" process assumed the form of a deep-seated political and ideological animosity which fixated on the notion of the perceived enemy as a sinister, destructive force. Thus, while American propaganda of this period conceived of its Soviet adversary as the monstrous "hydra-headed super-enemy" of Communist encroachment, a seemingly omnipresent foe whose shadowy agents operated not on the global stage of international conflict, but in the covert realm of espionage and infiltration, the Soviet popular imagination viewed its capitalist enemy as an equally malevolent threat. In this way, the primary cultural narrative which sustained the political tension of the Cold War period was one of radical difference and irreconcilable animosity.

\section{Comparative Literature and Dispelling the Narrative of Otherness}

My research seeks to move beyond such rigid paradigms, suggesting instead that, despite the vast cultural and ideological chasm separating them, these cultures shared similar fears and, consequently, the narrative of "Otherness" and radical difference that defined Cold War political discourse existed as little more than a constructed mythology. Thus, while a more than cursory glance at the histories of these cultures exposes a whole series of similar political anxieties and paranoiac fears, it is within the fictive realm of literature and 
fantasy that the true extent of such parallels becomes apparent. The two texts I will discuss in this article, although drawn from ostensibly diverse socio-cultural contexts, display similar preoccupations with such characteristically paranoid themes as hidden conspiracies, spying and surveillance. In comparing the manner in which these two literary works represent such anxieties, my research attempts to prove that while the Soviet Union and the America of the Cold War period initially appear as fundamentally irreconcilable adversaries, both cultures were consumed by similar fears and gripped by an equally pervasive paranoia, a paranoia whose origin was rooted more in the dark reality of internal political oppression and a pervasive sense of deep-seated suspicion than in the largely constructed narrative of an utterly demonised external foe.

\section{Representing Surveillance}

Reflecting the contemporary fascination with spying and espionage, a preoccupation born out of the precarious political situation that defined both the fledgling Soviet state and the anxiety-ridden America of the Cold War period, both The Master and Margarita and The Crying of Lot 49 construct vision and observation as central components of population monitoring and social control.

Composed during the height of the Stalinist purges of the 1930s, Bulgakov's vision of Soviet society is, as one historian writes, a vision of a social arena in which "the flywheel of repression [had] slipped out of the hands of those who were turning it" and, in doing so, had transformed the socio-cultural landscape into a terrifying realm of fear and suspicion. Depicting the numerous cruelties and abuses carried out by the Soviet Secret Police, Bulgakov's novel portrays Stalinist-era Moscow as an horrifically repressive society in which even the most mundane activities had become irrevocably intertwined with a "complicated process of surveillance and control". Thus, the world Bulgakov evokes is one in which a mixture of terror and anxiety surrounded the seemingly inescapable presence of the dreaded Secret Police, who appear throughout the novel as sinister, indistinct forms that spy on their fellow citizens and work to glean incriminating information by insinuating themselves into such seemingly innocent situations as "standing in a queue outside a store, frequenting the ... market, [or] listening to workers' complaints in the factory cafeteria..." (Fitzpatrick 164).

This vision of members of the sinister Secret Police engaged in a ceaseless process of spying on a terrified Soviet populace is a recurring image throughout The Master and Margarita, and succinctly encapsulates the pervasive paranoia of a culture in which the possibility of arrest and incarceration remained a constant threat. This sense of a culture dominated by the fear of falling under the scope of state surveillance manifests in the form of a recurring plot point whereby most of the novel's characters find themselves pursued by menacing, shadowy members of the Soviet Secret Police. In one such scene, two of the novel's central 
characters are followed by a series of sinister observing agents:

Although the footsteps of Azazello and Margarita fell lightly, a lone man heard them and began to shake restlessly... A second man, surprisingly like the first met them by the sixth entrance... The restless man looked around and frowned. When the door opened and closed, he left following the invisible enterers, looking into the passage, he, of course, saw no one. The third man, an exact copy of the other two, was on duty on the landing of the third floor. (MM 220)

Within this representative scene, Bulgakov conveys the profound anxiety of a society in which innumerable observing agents, primarily members of the Secret Police, pervaded the cultural landscape. Presenting such figures as an ever-present threat, Bulgakov succeeds in capturing the pervasive sense of fear and suspicion that thrived within the brutally oppressive climate of Soviet Moscow.

Resounding through decades of socio-political upheaval, a similar preoccupation with surveillance and observation can be seen in Thomas Pynchon's evocation of Cold War paranoia as depicted in The Crying of Lot 49. Set amidst the affluent suburbs of 1960s California, Pynchon portrays mid-twentieth century America as a society gripped by Cold War anxiety. The short, satirical novel is set amidst the hysteria and widespread suspicion of a culture in which the Cold War struggle against Communism played out as a covert battle in which, as one commentator notes, "the war was in all the world's filing cabinets... [and] the weapon was information". As such, Pynchon evokes the pervasive anxieties of a culture in which the preservation of democracy and freedom was viewed as dependent upon a complex system of surveillance and information-gathering. However, as such fears began to manifest in the repressive policies of America's post-war anticommunist witch hunts, a period commonly referred to as the McCarthy era after one of the driving forces behind this spate of political repression, an anxious American populace had begun to fear that their own body politic might shelter not only enemy infiltrators, but the sinister face of America's own oppressive political structures. Thus, while The Crying of Lot 49 is a novel concerned with portraying the unique socio-historical circumstances of the 1960s, it presents the American socio-political landscape of this period as a deeply suspicious, deeply paranoid society. In this way, Pynchon's novel adopts a profoundly unsettling series of visual motifs whereby he populates the novel with a seemingly endless stream of sinister figures, who, in their invariably shadowy appearances, appear to embody contemporary Cold War fears surrounding the almost unprecedented scope of state surveillance. By presenting these figures as an omnipresent, malevolent force, The Crying of Lot 49 mirrors the sinister aesthetic of The Master and Margarita. Echoing the profound sense of unease that pervades Bulgakov's novel, The Crying of Lot 49 thus creates a deeply unsettling vision of a culture in which a profound anxiety surrounded the presence of observing agents and surveillance systems. The similarities between these texts can be seen in the numerous scenes and images from The Crying of Lot 49 which recall events from Bulgakov's novel. One such example of the aesthetic and thematic parallels between the 
two novels occurs when Pynchon's inquisitive heroine, Oedipa Maas, finds herself plagued by the uncanny sensation that she is under some form of observation: "looking back, [she] could see their pursuer had been joined by another man about the same build. Both wore grey suits" . In scenes such as this, one can observe a profoundly paranoid social landscape, pervaded by the uneasy sense that the actions of its inhabitants are constantly under some sort of surveillance. Moreover, it is in this representation of a culture preoccupied by the presence of mysterious, observing figures that Pynchon's portrayal of America's Cold War paranoia most clearly echoes Bulgakov's exploration of the cultural anxieties of Stalinist-era Moscow. Indeed, by depicting the sinister figures that plague the heroine of his novel as shadowy, unnamed beings, Pynchon demonstrates a profound affinity with the sinister aesthetic found in Bulgakov's work and hints at the existence of shared fears so alike that they transcend ideological divides.

\section{Conclusion}

Early in The Crying of Lot 49, one character notes that falling under the gaze of surveillance structures is an inescapable part of the contemporary American condition, claiming that, "All the time, somebody listens in, snoops; they bug your apartment, they tap your phone". Due to the broad familiarity with American popular culture amongst most Western readers, such images of the deeply-ingrained social paranoia that plagued the American popular imagination during the Cold War period remain forever embedded within our general understanding of twentieth-century American history and culture. However, by exploring the manner in which Soviet literature of the Stalinist era expressed a similar fascination with images of surveillance, observation, and paranoia, my thesis maintains that, although both nations expended a great deal of energy convincing their citizens of the ethical, cultural and ideological Otherness of the rival superpower, a similar atmosphere of fear and mistrust thrived under both regimes. By exploring these texts from a historical, as well as from a psychoanalytic, prospective, my research attempts to highlight the fact that, despite the vast cultural and ideological differences separating these seemingly diverse socio-political systems, they shared a series of deeply-engrained anxieties which transcended rigid Cold War conceptions of Otherness.

With appreciation and gratitude to my supervisor, Dr. Alan Gibbs 